\title{
Impactos da crise sanitária da COVID-19 nos mercados de energia do Brasil ${ }^{*}$
}

\author{
Luciano Losekann ${ }^{\dagger}$ \\ Edmar Luiz Fagundes de Almeida \\ Niagara Rodrigues ${ }^{\S}$ \\ Francisco Teixeira Raeder ${ }^{\text {II }}$ \\ Diogo Lisbona Romeiro" \\ Gustavo Soares** \\ Yanna Clara Prade $e^{\dagger \dagger}$
}

\begin{abstract}
Resumo
Os mercados energéticos foram severamente afetados pela pandemia do novo coronavírus. As medidas adotadas para o enfrentamento da COVID-19, principalmente as restrições de mobilidade, resultaram em grandes reduções na demanda global de energia. As deficiências brasileiras com combate a pandemia tiveram impactos na dinâmica dos mercados energéticos. A redução do consumo de energia foi menos significativa do que os países que já passaram pelo auge da pandemia, mas tende a ser mais persistente. $\mathrm{O}$ artigo objetiva traçar um panorama dos impactos decorrentes da pandemia nos mercados de petróleo, combustíveis e biocombustíveis, gás e eletricidade, bem como discutir os desafios impostos no Brasil e traçar perspectivas a situação pós-pandemia.
\end{abstract}

Palavras-chave: Petróleo, Combustíveis, Biocombustíveis, Gás, Eletricidade

JEL: D40, L51, Q40

\footnotetext{
*Agradecemos os comentários e sugestões dos parceristas anônimos e dos editores da revista.

${ }^{\dagger}$ PPGE/UFF, E-mail: lucianolosekann@id.uff.br, ORCID: 0000-0001-7622-5909

${ }^{\ddagger}$ IE-PUC-RIO e IE-UFRJ, E-mail: edmar@ie.ufrj.br, ORCID:0000-0001-8068-2555

§PPGE/UFF, E-mail: niagararodrigues@ gmail.com, ORCID: 0000-0002-8958-9995

IDoutorado PPGE/UFF, E-mail: francisco.raeder@yahoo.com.br, ORCID: 0000-0001-8701-703X

"Centro de Estudos em Regulação e Infraestrutura da Fundação Getulio Vargas, E-mail:

diogo_lisbona@hotmail.com, ORCID: 0000-0002-1282-1645

**IE/UFRJ, E-mail: gustavo.also@ yahoo.com.br, ORCID: 0000-0002-1282-1645

†IE/UFRJ e Prysma, E-mail: yannaclara@gmail.com, 0000-0001-5070-0150
} 


\section{Introdução}

Como a totalidade da economia, o setor energético foi atropelado pela crise sanitária da Corona Virus Disease 2019 (COVID-19) ${ }^{1}$. A pandemia levou à uma forte redução da atividade econômica, e descortina-se um cenário de lenta retomada das atividades após o fim da emergência sanitária. Enquanto não houver uma solução definitiva para o problema sanitário, como o desenvolvimento de uma vacina, teremos que conviver com restrições em atividades econômicas para mitigar os riscos de novos surtos da COVID-19.

A crise tem se mostrado desafiadora para todos os setores da economia. Entretanto, o impacto no setor energético merece um cuidado especial. Em primeiro lugar, é fundamental impedir que a crise sanitária se transforme também em uma crise energética, com problemas na segurança do abastecimento de combustíveis e energia elétrica. Em segundo lugar, é necessário impedir que as consequências da crise ameacem a sustentabilidade da indústria, os interesses nacionais e toda a política energética nacional.

A emergência sanitária representa um grande desafio para produção de petróleo, em particular no segmento offshore. Esta indústria depende de uma cadeia logística muito complexa, internacionalizada e que opera em fluxo contínuo. Dada a relevância que o setor de exploração e produção de petróleo $(\mathrm{E} \& \mathrm{P})$ tem na economia nacional, torna-se estratégico para o país monitorar e garantir o funcionamento da cadeia logística do setor.

Medidas adotadas para mitigar a disseminação do vírus, como o isolamento social, constituem enorme adversidade para o setor de combustíveis automotivos. Como as medidas de contenção do contágio focam a restrição de circulação, a demanda por combustíveis no transporte despenca. Um grande obstáculo ao setor é manter funcionando uma logística de abastecimento dos mais 40 mil postos de combustíveis no país. No caso dos biocombustíveis, sobretudo etanol, existe uma perspectiva de excesso de oferta tendo em vista que a safra de cana-de-açúcar começou a ser colhida durante a pandemia, no mês de maio. O descompasso entre oferta e demanda põe em xeque a sustentabilidade das empresas do setor.

O contexto da indústria de gás natural antes da crise da COVID-19 era de grande otimismo e expectativa de grandes transformações. O governo atual fez uma aposta numa revolução energética no país, ancorada numa oferta abundante de gás do pré-sal a preços competitivos. O contexto atual traz diversos desafios para a concretização desse cenário. A crise sanitária e econômica desencadeada pela COVID-19 gerou impactos relevantes no curto prazo e tem potencial para mudar o panorama de investimentos e crescimento energético no médio e longo prazo.

No setor elétrico, a queda da demanda de energia coloca enorme pressão financeira

\footnotetext{
${ }^{1} \mathrm{O}$ novo coronavírus é uma nova cepa do vírus (2019-nCoV) que foi notificada em humanos pela primeira vez na cidade de Wuhan, na província de Hubei, na China. Desde o início de fevereiro de 2020, a Organização Mundial da Saúde (OMS) passou a chamar oficialmente a doença causada pelo novo coronavírus de Covid-19.
}

Econômica-Niterói, v. 22, n. 1, p. 31-57. Junho, 2020 
nas distribuidoras e nos agentes do mercado livre. As distribuidoras e grandes consumidores com contrato de longo prazo terão dificuldades para arcar com prejuízos financeiros associados à queda da demanda. Muitas empresas acionam cláusulas de força maior para evitar arcar com prejuízos financeiros, o que tende a levar a inadimplência cruzada e a um processo de judicialização crescente.

Nesse contexto, o objetivo do artigo é traçar um panorama acerca dos impactos da COVID-19 no setor energético brasileiro. Também serão elencados os desafios impostos e traçadas algumas perspectivas para os mercados energéticos no curto prazo e no póspandemia. Para isso, o artigo é estruturado em cinco seções, sendo quatro delas para cada um dos mercados (petróleo, combustíveis e biocombustíveis, gás natural e eletricidade) e uma para as considerações finais.

\section{Petróleo}

O ano de 2020 começou marcado por expectativas favoráveis no que se refere à retomada do setor de Exploração e Produção (E\&P) no Brasil. Além das projeções de melhoria no cenário econômico brasileiro, também se esperava um aumento no volume da produção de petróleo, sobretudo do óleo proveniente do pré-sal. Adicionalmente, era grande a expectativa com a retomada dos investimentos em E\&P devido às rodadas de partilha e de concessão realizadas pela ANP entre 2017 e 2018. Nestes leilões, grandes empresas internacionais do setor de petróleo se comprometeram com vultosos investimentos no E\&P no país, com destaque para ExxonMobil, Shell, BP e Equinor.

Inicialmente, as boas expectativas pareciam se confirmar já que, em janeiro de 2020, a produção de petróleo e gás natural registrou um recorde e superou, pela primeira vez no Brasil, o nível de 4 milhões de barris de óleo equivalente por dia (boe/d). No caso do petróleo, a produção foi de 3,186 milhões de barris por dia (bbl/d), crescendo 20,43

No entanto, alguns acontecimentos do mercado internacional de petróleo acabam impactando no mercado brasileiro. Para a indústria mundial, o cenário no início do ano estava caracterizado pelo expressivo aumento da produção de petróleo não convencional dos Estados Unidos, além do crescimento da oferta de outros países produtores, principalmente os membros da Organização dos Países Exportadores de Petróleo (OPEP), com destaque para Arábia Saudita, além da Rússia. Por outro lado, a demanda mundial de petróleo atravessava um período de crescimento menos expressivo, ditado, principalmente, pelo ritmo mais lento do crescimento econômico chinês. Descortinava-se um potencial desequilíbrio no mercado, um cenário de disputa pelo mercado asiático e uma crescente instabilidade no cartel da OPEP e países aliados (OPEP Plus).

Se o mercado internacional já se encontrava desequilibrado, a pandemia da COVID-19 trouxe ainda mais instabilidade. Medidas de isolamento levaram à uma drástica redução da mobilidade, representando um choque imediato na demanda de petróleo. De acordo 
Gráfico 1 - Evolução do transporte rodoviário (esquerda) e do número de voos (direita) em 2020
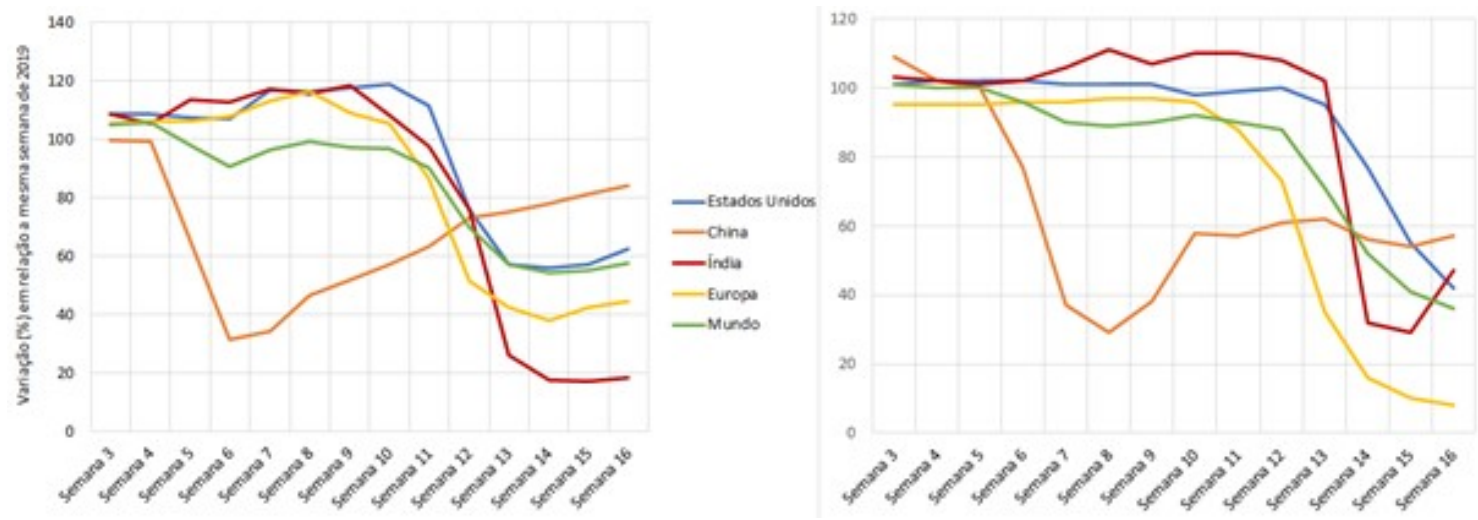

Fonte: IEA (2020a)

com a IEA (2020a), 57\% da demanda mundial de petróleo ocorre no segmento de transporte.

O primeiro país afetado pela pandemia foi a China, que é um dos maiores demandantes de petróleo. No país asiático, a queda brusca na demanda por petróleo se iniciou em janeiro. Em março, novos epicentros da pandemia surgiram, com destaque para a Europa e Estados Unidos. Foi também nesse mês que a Índia, que concentra uma população de mais de 1 bilhão de habitantes, decretou o lockdown. As medidas de restrição de mobilidade geraram uma redução do consumo mundial de petróleo em cerca de 29 milhões de barris/dia no mês de abril (IEA, 2020a). Os impactos da mobilidade restrita estão destacados no Gráfico 1.

A combinação de excesso de oferta e queda de demanda atingiu de tal magnitude o mercado de petróleo que passou a representar uma ameaça real ao seu próprio funcionamento. Esta ameaça está relacionada com a falta de capacidade de estocagem para petróleo excedente produzido. Este problema ficou claro nos Estados Unidos quando o preço do WTI atingiu a faixa dos US\$37,00 negativos no dia 20/04/2020 (EIA, 2020a). Os players do mercado futuro tiveram que aceitar preços negativos para evitar que os contratos vencessem, o que geraria a necessidade da retirada física do óleo. Como não havia onde armazenar o petróleo, a opção da retirada física simplesmente não existia, o que gerou grande distorção no mercado, que ficou com muito mais vendedores que compradores.

O problema da falta de estocagem também gerou distorções no mercado fora dos Estados Unidos. A busca por locais não convencionais para armazenamento, como navios petroleiros, inflacionou o preço do frete de petróleo. Com menos navios disponíveis para o transporte de óleo, o frete diário dos navios disparou, ameaçando a viabilidade econômica

Econômica-Niterói, v. 22, n. 1, p. 31-57. Junho, 2020 
das exportações petrolíferas.

Posteriormente, a cooperação entre os países da OPEP e demais grandes países produtores (inclusive o Brasil) para implementar cortes emergenciais de produção surtiu efeito imediato no mercado de petróleo. Os preços do petróleo se recuperaram no mês de maio deixando a sensação de que o pior momento da crise tinha passado.

Conforme alguns países vão relaxando algumas medidas de isolamento e retomando suas atividades econômicas, a demanda de petróleo vai se recuperando. Para o fim de 2020, é esperado que a demanda se recupere, mas que não volte ao mesmo patamar de dezembro de 2019, sendo 9\% menor (IEA, 2020a). Espera-se que a China retome a demanda antes dos demais países, já que foi o primeiro país afetado pela pandemia. A retomada da China daria um certo alívio para o mercado, uma vez que os chineses são os maiores importadores mundiais de petróleo.

A despeito das incertezas sobre o comportamento dos preços nos curto e médio prazos, existe um consenso de que a nova trajetória de preços estará muito abaixo da média dos últimos três anos. As principais projeções apontam para um cenário de preços em patamares mais baixos por um horizonte mais longo de tempo, girando em torno de US\$ 30,00 a 35,00, para 2020, e US\$ 43,00 a 47,00, para 2021, por barril (EIA, 2020b). O mercado mundial de petróleo precisará de tempo para digerir os grandes estoques de petróleo. Enquanto isto não acontece é remota uma retomada de preços para os patamares de antes crise sanitária.

Com o cenário de lower for longer cada vez mais provável, as empresas do setor não têm outra escolha senão realizar fortes ajustes no seu planejamento estratégico, com redução de investimentos e cortes expressivos de custos para manterem seu caixa e garantir sua sustentabilidade. Este processo de ajuste certamente trará repercussão importante para o setor no Brasil.

A Petrobras, principal investidora no segmento de E\&P brasileiro, foi diretamente afetada pela queda nos preços e pela redução da demanda de derivados no país. As vendas de gasolina e diesel caíram $28 \%$ e $14 \%$, respectivamente, no mês de abril, em relação ao mesmo mês de 2019. O caso do querosene de aviação (QAV) foi ainda mais negativo, em que as vendas despencaram 85\% (ANP, 2020b).

Em contrapartida à queda na demanda no Brasil, as exportações de óleo bruto e derivados se revelaram uma surpresa positiva. A Petrobras bateu recorde de exportação de petróleo no mês de abril, quando exportou 1 milhão de barris por dia; o recorde anterior, de dezembro de 2019, era de 771 mil barris (Petrobras, 2020a). A empresa está direcionando seus esforços para a exportação devido à contração da demanda interna. O principal comprador é a China, que foi responsável por $60 \%$ das vendas de petróleo exportado. Isso se deve ao fato de a economia chinesa já demonstrar sinais de recuperação após a violenta contração ocasionada pela COVID-19. Em janeiro de 2020, as exportações brasileiras de petróleo foram de 29,52 milhões de barris; em abril, 47,44 milhões (ANP, 2020c). Nesse contexto, fica claro que o Brasil segue uma tendência de rápido crescimento das 
exportações de petróleo.

Esse esforço em direcionar as exportações para o mercado externo é especialmente benéfico à Petrobras, principalmente em relação às suas finanças. A medida consiste em um importante reforço de caixa para a empresa em um momento crítico. Vale ressaltar que a receita decorrente das exportações é em dólar e, desde janeiro até abril de 2020, a moeda americana se valorizou em torno de $35 \%$ frente ao real (BCB, 2020).

Embora o aumento das exportações tenha sido bastante positivo, a Petrobras reportou um prejuízo de $\mathrm{R} \$ 48,5$ bilhões no $1^{\circ}$ trimestre de 2020 . O resultado foi fortemente impactado pela revisão das premissas de longo prazo para o Brent, que levou ao impairment de ativos no valor de $\mathrm{R} \$ 65,3$ bilhões (Petrobras, 2020b). De toda forma, a Petrobras demonstrou grande agilidade de adaptação e gestão da liquidez, salvaguardando uma posição de caixa robusta para atravessar o momento de turbulência do mercado mundial de petróleo.

Entretanto, os impactos da COVID-19 sobre o setor de petrolífero nacional serão duros. No curto prazo, a produção deverá sofrer com a decisão da Petrobras de realizar cortes em campos de custos mais elevados (Petrobras, 2020c). Adicionalmente, o setor já sente os efeitos dos cortes nos gastos e renegociação de contratos com os fornecedores por parte da Petrobras e outros operadores.

O menor apetite por investimentos em E\&P fez com que a Agência Nacional do Petróleo (ANP) suspendesse as próximas rodadas de licitação de blocos exploratórios, até então previstas para ocorrer no segundo semestre de 2020 (ANP, 2020d). Além disto, a ANP estabeleceu novos procedimentos para as empresas atuantes no setor de E\&P em direção a uma flexibilização de obrigações contratuais. Dentre eles, destacam-se a prorrogação em nove meses da Fase de Exploração dos Contratos de E\&P e a permissão de variação superior a $15 \%$ no volume produzido em relação ao volume previsto.

A médio prazo, os fluxos de investimentos podem sofrer importante revés com a ajuste das operadoras ao contexto de menor preço de petróleo e uma maior competição entre as diferentes províncias petrolíferas mundiais pelos investimentos das empresas internacionais. A crise atual será um vetor de grandes transformações na indústria mundial de petróleo. Apesar de ainda ser cedo para vislumbrar todos os impactos trazidos pela COVID-19, já podemos dizer que se trata de um impacto disruptivo. Estas transformações disruptivas gerarão ganhadores e perdedores entre países e empresas. Assim, as empresas posicionadas no Brasil e as autoridades energéticas precisam trabalhar rápido e de forma determinada para que o E\&P brasileiro não se posicione no lado dos perdedores.

Para isto, é importante uma estratégia de inovação agressiva aproveitando o ecossistema de inovação Brasileiro. As cláusulas de P\&D permitiram o desenvolvimento de um grande ecossistema de inovação, envolvendo fornecedores, universidades e start-ups tecnológicas. A adaptação ao contexto de lower for longer requer a manutenção do esforço inovativo, a despeito da maior restrição financeira atual. Ressalta-se que outras geografias que concorrem com o Brasil, como o shale oil americano, usarão a inovação como

Econômica-Niterói, v. 22, n. 1, p. 31-57. Junho, 2020 
principal estratégia de adaptação, tal como já fizeram na crise do petróleo de 2014.

\section{Combustíveis}

Em virtude das medidas de isolamento social impostas para redução do contágio do novo coronavírus, o setor de combustíveis foi severamente afetado, principalmente por sua estreita relação com o transporte. A análise do setor de combustíveis pode ser subdivida em duas partes. Na primeira delas, a ênfase recai sobre os combustíveis derivados do petróleo. Nesse caso, a dinâmica dos preços dos combustíveis é fortemente afetada pelo mercado de petróleo cru. Na segunda, o foco é o setor de biocombustíveis. Devido a algumas particularidades do setor, os impactos decorrentes da pandemia podem ser mais fortes.

\subsection{Combustíveis derivados do petróleo}

Conforme destacado, o segmento de transportes foi diretamente afetado pela pandemia da COVID-19, já que o consumo de combustíveis se reduz ao passo que são implantadas medidas que restringem a mobilidade da população. Em relação às vendas, o impacto foi negativo para os três principais combustíveis, a saber: diesel, gasolina e querosene de aviação (QAV). Entretanto, o padrão de queda na demanda não foi homogêneo, como pode ser observado no Gráfico 2.

As vendas de combustíveis deterioraram na segunda quinzena de março, quando iniciou o isolamento social no Brasil. Os resultados das vendas de gasolina e QAV apresentaram relevante piora em relação ao mesmo mês do ano anterior; enquanto o diesel, ainda registrava aumento na quantidade comercializada. A situação em abril, no entanto, ficou ainda mais crítica, uma vez que as vendas recuaram para todos os combustíveis, variando de $-13,92 \%$ para o diesel, $-28,51 \%$ para a gasolina e $-84,73 \%$ para o QAV.

No caso do diesel, o combustível é fortemente utilizado para o transporte de mercadorias (caminhões) e de passageiros (ônibus). Apesar de ter ocorrido uma queda expressiva do transporte urbano, o escoamento da safra para exportação ${ }^{2}$ sustentou o transporte de cargas. As dimensões continentais do país, tendo o modal rodoviário como a principal forma de transporte e escoamento de produtos acabaram amortecendo, em algum grau, a queda nas vendas do diesel. As vendas de gasolina são orientadas ao transporte individual, que foi mais afetado pelo isolamento social. A queda na demanda por QAV se

\footnotetext{
${ }^{2}$ Os fluxos de março e abril cresceram com a safra recorde, câmbio favorável e exportação represada do início do ano por conta, principalmente, das medidas restritivas nos portos chineses para combater a disseminação do novo coronavírus. Essa combinação de fatores, levou as exportações brasileiras de soja em grão a bater recorde de envios no mês de abril, contabilizando um crescimento de $57,07 \%$ em valores monetários e 63,36\% em quantidade (kg) ante o mesmo mês de 2019, segundo dados do MDCI (2020).
} 
Gráfico 2 - Variação mensal nas vendas de combustíveis no Brasil - 01/2020 a 04/2020

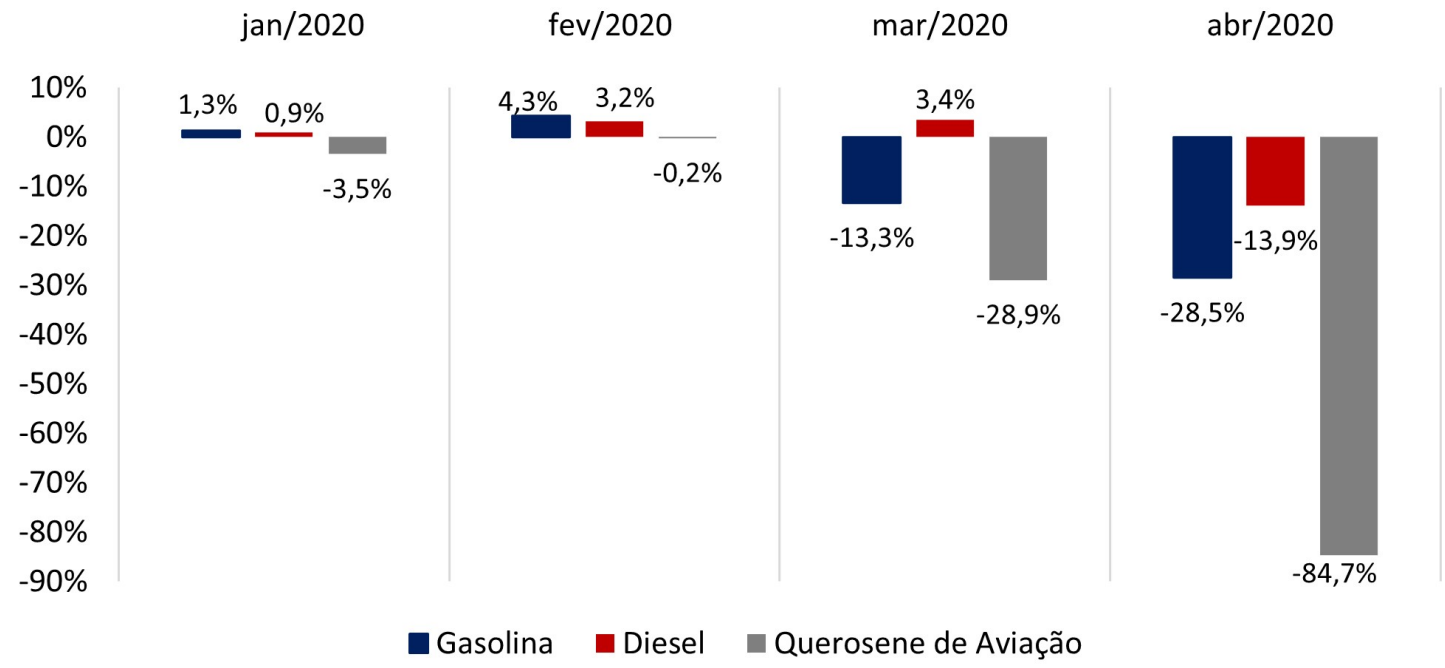

Fonte: Elaboração própria a partir de ANP (2020b)

mostra mais expressiva, uma vez que o número de voos ao redor do mundo foi drasticamente reduzido ${ }^{3}$.

A rápida redução da demanda por derivados promove efeitos desestruturantes na cadeia produtiva de derivados. A Petrobras anunciou redução da produção de petróleo por dificuldades de escoamento para mercados, em 200 mil barris/dia. Ademais, dados do MME (2020a) apontam uma redução no fator de utilização do parque de refino brasileiro. No início de março, a utilização se encontrava entre $75 \%$ e $80 \%$. Em contra partida, esse patamar foi reduzido para pouco mais de $50 \%$ nas duas primeiras quinzenas de abril. Nesse cenário de demanda reduzida, as empresas distribuidoras negociaram com a Petrobras a flexibilização das cláusulas take or pay para evitar o compromisso de compra de combustível.

Em relação aos preços dos derivados, é importante frisar que, desde outubro de 2016, a estratégia de precificação de derivados nas refinarias da Petrobras é pautada pelo alinhamento com o mercado internacional de curto prazo (Petrobras, 2016). Nesse sentido, as reduções do preço do petróleo, no mercado internacional, foram repassadas pela Petrobras aos preços domésticos. No entanto, a forte desvalorização do Real compensou parte

\footnotetext{
${ }^{3}$ Os desempenhos mais fracos foram registrados em abril, auge do impacto da pandemia do novo coronavírus no setor. A demanda por voos domésticos registrou queda de $90,97 \%$ e a demanda por voos internacionais, operados pelas companhias aéreas brasileiras, recuou 96,85\% em maio, em relação ao mesmo período do ano passado (ABEAR, 2020).
}

Econômica-Niterói, v. 22, n. 1, p. 31-57. Junho, 2020 
da redução e os preços dos combustíveis na bomba não recuam na mesma velocidade da queda nas refinarias, como pode ser observado na Tabela 1.

Tabela 1 - Variação dos preços da gasolina e do diesel na refinaria e na bomba em 2020

\begin{tabular}{ccccc}
\hline & \multicolumn{2}{c}{ Gasolina } & \multicolumn{2}{c}{ Diesel } \\
\hline Período & Refinaria & Bomba & Refinaria & Bomba \\
Acumulado 06/01 a 02/03 & $-8,12 \%$ & $-0,59 \%$ & $-15,43 \%$ & $-3,22 \%$ \\
02/03 a 09/03 & $-3,06 \%$ & $-0,35 \%$ & $-2,65 \%$ & $-1,17 \%$ \\
09/03 a 16/03 & $-6,58 \%$ & $-0,64 \%$ & $-6,05 \%$ & $-0,88 \%$ \\
16/03 a 23/03 & $-9,26 \%$ & $-1,92 \%$ & $-3,81 \%$ & $-2,62 \%$ \\
23/03 a 30/03 & $-6,10 \%$ & $-2,32 \%$ & $-2,41 \%$ & $-1,58 \%$ \\
30/03 a 06/04 & $0,62 \%$ & $-3,47 \%$ & $-0,17 \%$ & $-2,88 \%$ \\
06/04 a 13/04 & $-3,93 \%$ & $-1,30 \%$ & $-2,61 \%$ & $-0,60 \%$ \\
13/04 a 20/04 & $-4,63 \%$ & $-2,52 \%$ & $-4,93 \%$ & $-2,08 \%$ \\
20/04 a 27/04 & $-1,86 \%$ & $-1,58 \%$ & $-6,38 \%$ & $-1,42 \%$ \\
\hline Acumulado 02/03 a 27/04 & $-30,18 \%$ & $-13,29 \%$ & $-25,71 \%$ & $-12,51 \%$ \\
\hline
\end{tabular}

Fonte: Elaboração própria a partir de ANP (2020e) e ANP (2020f)

A existência de ajustamentos assimétricos de preços entre vendedores e revendedores pode se manifestar de diversas formas e ter mais de uma razão para ocorrerem. Em mercados imperfeitamente competitivos do tipo price-searcher, a dispersão nos preços observados é consistente com o custo de pesquisa do consumidor. Custos com tempo gasto de pesquisa geram poder de mercado temporário para os postos de abastecimento, uma vez que o consumidor só é levado a pesquisar quando tem a percepção de que as perdas envolvidas em um aumento de preço superam os custos da procura por um combustível mais barato. Sabendo disso, os varejistas postergam as reduções de preço quando o preço cai no atacado, produzindo a assimetria. Em tempos de medidas de distanciamento social, o custo de deslocamento em busca de combustível mais barato aumenta e o mesmo ocorre com o poder de mercado dos postos de abastecimento.

$\mathrm{Na}$ literatura de assimetria de precificação, é comum utilizar a ilustração do "foguete e pena" para retratar mercados de combustíveis (Bacon, 1991). Em momentos de aumento de preço de insumos (gasolina e diesel na refinaria), os preços finais (gasolina e diesel nas bombas) aumentam rapidamente, como um "foguete". Em momentos de queda de preços nas refinarias, como observamos nos últimos meses, a diminuição dos preços finais ocorre de forma mais lenta, como uma "pena".

\subsection{Biocombustíveis}

A crise da COVID-19 frustrou as grandes expectativas quanto à evolução dos biocombustíveis no Brasil. No caso do etanol, a safra de 2019/2020 obteve bom resultado da 
produção de cana, cerca de 642 milhões de toneladas, e recorde na produção de etanol (35 bilhões de litros) (CONAB, 2020). Ao que tudo indicava, a nova safra (2020/2021) repetiria os bons resultados. No caso do biodiesel, os ânimos também estavam elevados. $\mathrm{O}$ aumento da mistura obrigatória de biodiesel estava evoluindo rápido e, em 2020, alcançou 12\% (B12). Movimentos políticos pressionavam a expansão para o B15 e testes para o B20 estavam em andamento. Também vale ressaltar que, em 2019, houve recorde na produção de biodiesel (5,9 bilhões de litros).

Gráfico 3 - Faixa de operação de preço, nas distribuidoras, do etanol hidratado em São Paulo

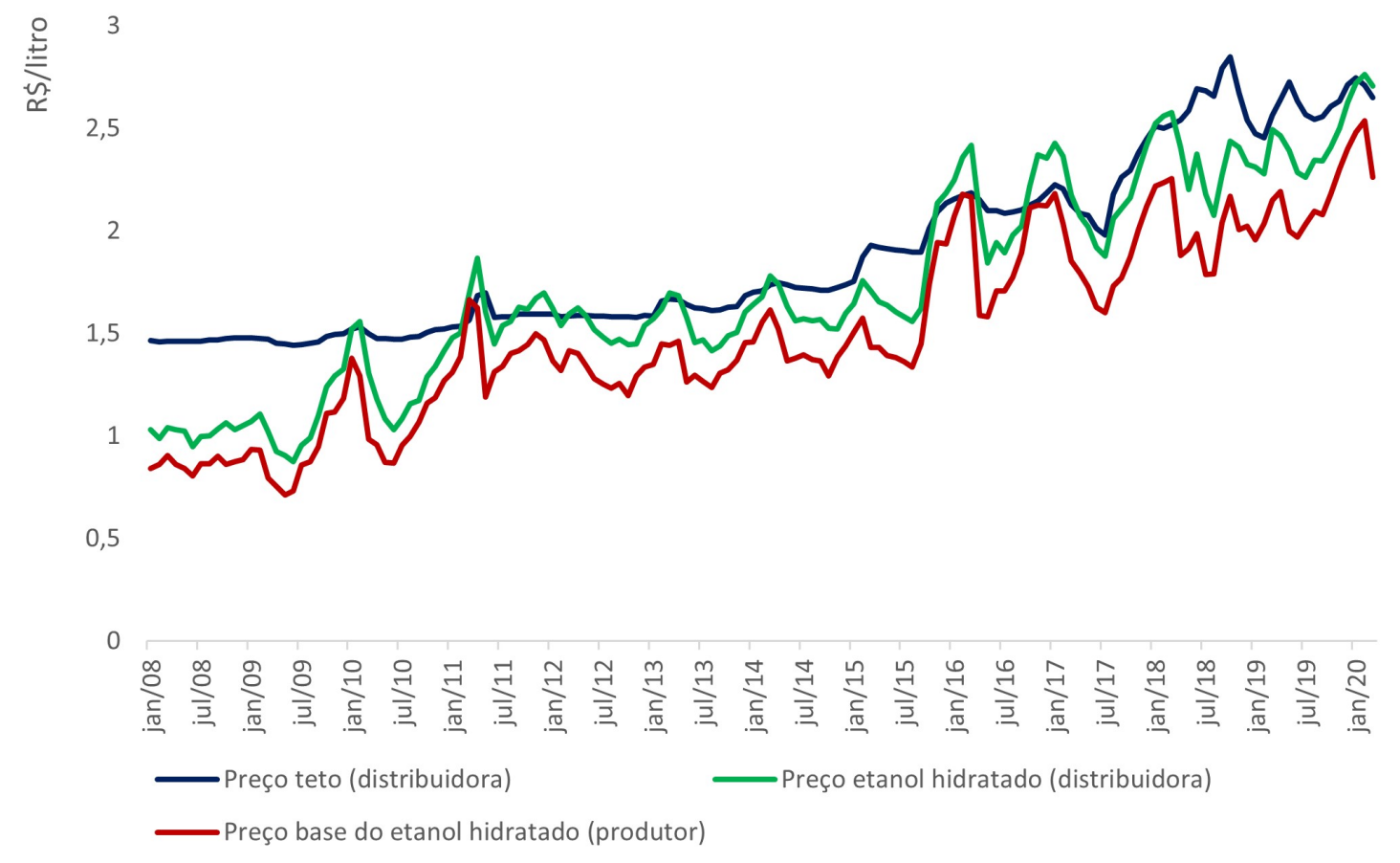

Fonte: elaboração própria com dados ANP (2020e) e CEPEA (2020).

O coronavírus, no entanto, foi um divisor de águas e o ambiente favorável foi rapidamente transformado em um cenário desolador. O principal desafio imposto foi a drástica queda na demanda de combustíveis com a redução de mobilidade. A crise foi potencializada com a queda dos preços do petróleo que prejudicou a competitividade do etanol hidratado em relação à gasolina (Gráfico 3), já que, no Brasil, a maioria dos veículos são flex fuel. Nesse sentido, gasolina e etanol figuram produtos substitutos.

Ademais, os custos de produção do etanol têm crescido desde 2009, principalmente em decorrência da queda da produtividade da cana-de-açúcar. Dentre os fatores que explicam o aumento do custo de produção, podemos citar o aumento dos custos de arren- 
damento da cana fornecida por terceiros, o aumento do custo de mão de obra, o aumento do custo de fertilizantes e o aumento do custo de investimento industrial (Milanez et al, 2012). Além desses fatores conjunturais, existem fatores estruturais gerando efeitos negativos sobre os resultados das tecnologias agrícolas e, consequentemente, sobre o próprio desempenho do setor (Nyko et al, 2013). Isto é, as tecnologias tradicionais parecem ter atingido um limite de ganhos de produtividade. Nesse sentido, as margens do setor se mostram bastante pressionadas.

O Gráfico 3 apresenta a margem de atuação do etanol hidratado apenas para o Estado de São Paulo, maior Estado produtor. A linha teto (em azul) refere-se a 70\% do preço da gasolina vendido pelas distribuidoras, que é o preço equivalente da gasolina ao litro de etanol, pois o conteúdo energético da gasolina é 30\% superior ao etanol. Mesmo São Paulo sendo um dos Estados onde o etanol apresenta-se competitivo, é possível observar que as margens operacionais são estreitas.

Uma outra característica da produção do etanol que intensifica os efeitos negativos da atual crise é o seu caráter sazonal. A produção do etanol eleva-se no período de colheita da cana que, na região Sudeste, principal região produtora, ocorre entre os meses de abril e novembro. Nesse contexto, a produção cresce aceleradamente a partir de março, coincidindo com o início da crise. Por razões técnicas, adiar a colheita da cana gera perdas de produtividade e a cana colhida não pode ser estocada pois, após o corte, a cana perde o açúcar rapidamente. Desta forma, não há outra opção a não ser processar a cana de açúcar.

Muitas usinas de etanol, principalmente na região Sudeste, também produzem açúcar e, assim, há flexibilidade de escolha entre os produtos. O cenário atual é favorável para o mercado de açúcar já que o real desvalorizado e a queda da produção de grandes concorrentes (em especial a Índia, e Tailândia) incentivam as exportações do adoçante. A tendência, portanto, é que os usineiros maximizem a produção do açúcar em detrimento da produção de etanol.

No entanto, a flexibilidade das usinas não é plena e cerca de $30 \%$ delas produzem exclusivamente etanol. Assim, o excedente da produção de etanol deverá acarretar no aumento da estocagem. A situação é particularmente grave para o Centro Oeste, onde muitas usinas não são flexíveis e está localizada apenas $26 \%$ da capacidade de estocagem. A região Sudeste que detém $62 \%$ dos estoques (ANP, 2020g)

No caso do etanol anidro, a competitividade é um fator menos crítico para a demanda, que é determinada por mandatos regulados. O mesmo ocorre com o biodiesel, que sofreu menos pela demanda de diesel não ter caído tanto quanto a demanda por combustíveis do ciclo Otto (etanol e gasolina).

Porém, o setor não saiu ileso. Com os impactos da crise, o governo flexibilizou as regras de retirada do biodiesel contratados nos leilões. Antes, as distribuidoras necessitavam retirar no mínimo $95 \%$ do biodiesel comprado nos leilões, pagando multa por litro não retirado. Agora, com a flexibilização, as distribuidoras podem retirar no mínimo $80 \%$ 
do valor adquirido sem a aplicação de multas. Ou seja, o que de fato ocorreu foi uma redução no consumo do biodiesel dado que as distribuidoras podem reduzir em $20 \%$ os compromissos de compra nos leilões. A ANP (2020h) também reduziu temporariamente o percentual de biodiesel misturado ao diesel de $12 \%$ para $10 \%$ de 16 a 21 de junho de 2020.

Os usineiros têm demandado do governo medidas que recuperem a competividade do etanol. Neste sentido, solicitaram a elevação da CIDE sobre a gasolina e a isenção do PIS-COFINS sobre o etanol, ambos impostos federais. No entanto, o governo, com o argumento de que não há como beneficiar um setor em detrimento de outro, já que todos foram impactados, descartou qualquer mudança. Resta aos diferentes Estados, por meio do ICMS, decidirem se ampliam ou não a diferença de alíquotas entre os combustíveis.

Outra demanda setorial é a criação de linhas de créditos específicas para o financiamento de nova capacidade de estoques. Esse ponto é crítico para $30 \%$ das usinas que são inflexíveis e concentram-se majoritariamente na região Centro-Oeste. O BNDES aprovou em 04/06/2020 a criação de uma linha de financiamento de $\mathrm{R} \$ 3$ bilhões para estocagem de etanol combustível (BNDES, 2020). Estimativas apontam que a quantia garantiria a estocagem de até 6 bilhões de litros de etanol.

Para o Biodiesel, a principal demanda é a antecipação do B13, prevista para 2021, isto é, ampliar a mistura obrigatória de biodiesel de $12 \%$ para $13 \%$. Argumenta-se que há viabilidade técnica para a mistura e que a oferta de biodiesel tem sido mais que suficiente para atender as exigências demandadas.

\section{Gás Natural}

A crise sanitária da COVID-19 afetou todos os mercados de gás e gás natural liquefeito (GNL) com queda histórica da demanda e pressão sobre os preços locais e internacionais. O choque de demanda chegou em um mercado que já estava em condições fracas de consumo e com estoques mais elevados que a média, devido ao inverno mais ameno que o esperado. Na Europa, após o período do inverno, os estoques estavam ainda $55 \%$ cheios e com 25 bilhões de metros cúbicos a mais em comparação com a média dos últimos cinco anos (IEA, 2020b).

A demanda de gás europeia caiu $7 \%$ nos cinco primeiros meses de 2020 , em comparação com o mesmo período de 2019. O impacto foi sentido especialmente no setor elétrico, com redução do consumo de gás entre $10 \%$ e $60 \%$ nos países durante o período de lockdown. Nos Estados Unidos, a demanda de gás caiu 2,8\% no período de janeiro a maio em relação ao ano anterior - a redução não foi tão drástica pois o consumo de gás para geração elétrica aumentou em substituição ao carvão (IEA, 2020b).

A redução da demanda de gás e GNL mundial gerou forte impacto nos preços, que têm registrado baixas históricas. O GNL spot tem sido negociado a valores próximos a

Econômica-Niterói, v. 22, n. 1, p. 31-57. Junho, 2020 
US\$ 3/MMBtu e os preços de gás europeus e dos EUA têm se alinhado próximo a US\$ 2/MMBtu (MME, 2020b). A alta disponibilidade de GNL no mercado internacional nos curto e médio prazos irão manter os preços de GNL spot mais baixos. Os contratos de longo prazo de gás e GNL também sofreram impactos nos preços, dado que muitos deles são indexados ao preço do petróleo, que também está em patamares inferiores aos de 2019.

A demanda de gás no Brasil segue a mesma trajetória que os demais países consumidores. De acordo com dados do MME (2020b), a demanda total de abril foi de 54 $\mathrm{MMm}^{3} / \mathrm{d}$, uma redução de $17 \%$ com relação ao mesmo dado de 2019. A maior queda em termos de volumes foi do segmento industrial das distribuidoras, com uma redução de 9 $\mathrm{MMm}^{3} / \mathrm{d}$ na comparação ano a ano, o que significou uma queda de $33 \%$. Os segmentos automotivo e comercial foram mais afetados, devido às restrições de locomoção da população. A demanda do segmento comercial teve uma queda de $42 \%$ e o automotivo de 45\% em abril, em comparação com o mesmo período de 2019.

Para lidar com a redução da demanda de gás, as distribuidoras locais negociaram a flexibilização dos contratos de suprimento com a Petrobras, que incluiu a suspensão das cláusulas de take-or-pay e ship-or-pay e parcelamento das faturas dos meses de abril, maio e junho (Petrobras, 2020d). Diante da redução da demanda de gás no Brasil, a Petrobras teve de ajustar seu portfólio para lidar com a menor retirada de gás do sistema. Do lado da produção, a estatal paralisou alguns campos com produção mais custosa, tendo em vista também a relevante queda do preço do petróleo. A redução de oferta doméstica mais relevante, no entanto, foi proveniente do aumento da reinjeção de gás tanto em campos do pré-sal como no pós-sal, alcançando o patamar recorde de $46 \%$ da produção bruta de gás em março, mantido em abril (ANP, 2020i).

A Petrobras também declarou força maior com o consórcio de Manati, para suspender as obrigações do take-or-pay - a estatal tem um contrato de gás de longo prazo com o consórcio que inclui a Enauta, Petrorio e Geopark. Desde março, a produção do campo está paralisada, de acordo com dados da ANP (2020i). O consórcio busca negociar algum pagamento mínimo com a Petrobras para não afetar o fluxo de caixa das empresas do consórcio.

Do lado das importações, a Petrobras também declarou força maior e negociou com a YPFB as condições de redução da obrigação de take-or-pay. O aditivo assinado em março previa uma retirada mínima de $14 \mathrm{MMm}^{3} / \mathrm{d}$, com máximo de $20 \mathrm{MMm} 3 / \mathrm{d}$. Já em março a Petrobras importou $13,9 \mathrm{MMm}^{3} / \mathrm{d}$, reduzindo para $10,5 \mathrm{MMm}^{3} / \mathrm{d}$ em abril (MME, 2020b). No entanto, a YPFB afirmou que uma redução tão relevante da retirada do gás colocava em risco a integridade dos reservatórios. As empresas negociaram um contrato interruptível para o mês de maio de $4 \mathrm{MMm}^{3} / \mathrm{d}$, para cobrir o déficit de retirada - provavelmente com preços mais atrativos para incentivar a retirada de gás.

Por um lado, a Petrobras está se esforçando para cortar a disponibilidade de gás do sistema via importação da Bolívia e produção doméstica, por outro lado, as importações 
de GNL por parte da estatal aumentaram entre março e abril. A Petrobras anunciou que iria revender as cargas programadas para chegarem em abril e maio, porém não há registros nos dados de exportação do Brasil até o momento. Mas dado que os preços de GNL no mercado spot estão muito atrativos, é possível que a importação de GNL esteja sendo mais econômica que a importação do gás boliviano e a produção doméstica de alguns campos. De fato, as cargas importadas pela estatal em abril e maio custaram em média US\$ FOB 3,5/MMBtu, valores muito inferiores à faixa de US\$ FOB 10-15/MMBtu das cargas que foram importadas entre 2011 e 2014.

O contexto prévio a crise sanitária da COVID-19 era de grande expectativa para liberalização do mercado de gás, com a entrada de novos players, maior competição e redução significativa do preço do gás. As incertezas geradas pela crise internacional nos mercados de energia colocam um freio nas decisões de investimento do upstream, desacelerando também os investimentos já em andamento.

Resta saber como será o apetite desses investidores no médio e longo prazo para projetos de monetização de gás natural. O pré-sal estava muito bem posicionado entre as oportunidades globais, devido ao grande potencial de produção de petróleo. A decisão com relação ao gás dependia da reforma regulatória que garantiria acesso desses potenciais produtores ao mercado de gás brasileiro.

A reforma desenhada pelo Novo Mercado de Gás (NMG) tem três frentes de atuação complementares: i) os compromissos assumidos pela Petrobras no $\mathrm{TCC}^{4} \mathrm{com}_{\text {o }} \mathrm{CADE}^{5}$; ii) a agenda regulatória da ANP para introdução da competição; iii) e o aprimoramento das regulações estaduais (CNPE, 2019). Para que o objetivo de preços competitivos de gás seja alcançado é fundamental que as questões regulatórias se resolvam, principalmente com relação ao TCC e a agenda regulatória da ANP.

Algumas dessas frentes têm seguido o andamento esperado e não foram afetadas pelo contexto da crise sanitária. No âmbito do esforço do TCC do CADE, a agenda de desinvestimentos e abertura de elos da cadeia parece estar mantida pela Petrobras, que está seguindo com os processos de desinvestimento das participações remanescentes das transportadoras e da Gaspetro, e estruturando o modelo de acesso às Unidades de Processamento de Gás Natural.

Outro ponto relevante é o acesso a infraestrutura de escoamento de gás da Petrobras, que é um dos compromissos assumidos pela estatal. Nesse caso específico, além da necessidade de estabelecer um modelo de acesso, é relevante incentivar investimentos para expansão. Em uma nova abordagem para a resolução do entrave no escoamento, o BNDES assumiu o papel de incentivador do desenvolvimento de uma rede compartilhada de escoamento do gás do pré-sal.

No entanto, a resolução de alguns pontos essenciais para a reforma do mercado de

\footnotetext{
${ }^{4}$ Termo de Compromisso de Cessação.

${ }^{5}$ Conselho Administrativo de Defesa Econômica.
} 
gás está com andamento mais lento, provavelmente justificada pelo foco dos esforços das instituições governamentais de lidar com a atual crise sanitária e necessidade de readaptação da força de trabalho. Um dos principais pontos que necessita revisão e maior debate é sobre o modelo desenhado para o acesso ao transporte. Depois da tentativa frustrada de estabelecer novos compradores de capacidade para o Gasbol $^{6}$ não se apresentaram soluções ainda para os impasses evidenciados no processo.

A agenda regulatória da ANP, no âmbito do NMG, prevê que em 2020 seriam endereçadas as questões de interconexão de gasodutos, os critérios de autonomia e independência dos transportadores e a Revisão da Resolução ANP n ${ }^{\circ} 15 / 2014$, relativa a tarifas de transporte (ANP, 2019). Como as audiências e consultas públicas da agência estão suspensas devido à crise sanitária é possível que a agenda regulatória atrase, o que dificulta o andamento da reforma.

Os incentivos para aprimoramento da regulação estadual também não têm sido amplamente endereçados, tendo algumas iniciativas pontuais em alguns Estados, mas ainda longe de estar harmonizado em condições que incentivem a criação do mercado livre. Uma das diretrizes do NMG era a privatização de distribuidoras sob controle estatal e alguns Estados estão organizando o processo (como Espírito Santo, Rio Grande do Sul, Sergipe, Maranhão e Mato Grosso do Sul), mas ainda distantes de concretizarem o plano.

Mais importante que a privatização está o estabelecimento de regulação para o mercado livre, que está avançando em alguns poucos Estados. Por exemplo, no Estado do Rio de Janeiro, a Agenersa ${ }^{7}$ divulgou a nova regulação referente as condições para o mercado livre criando tarifas especificas para consumidor livre e consumidores com gasodutos dedicados. No Amazonas também se iniciou o processo de abertura do mercado de gás, mas vem enfrentando muita dificuldade política para avançar.

Outra questão relevante é que alguns pontos chaves que necessitam de solução regulatória, como a expansão de malha de transporte, acesso de terceiros a infraestruturas essenciais, e estabelecimento de armazenamento de gás; só podem ser endereçados através da Nova Lei do Gás. A lentidão no processo, que está desde 2016 em andamento, prejudica fortemente o setor, que necessita de segurança jurídica para realizar os investimentos necessários.

No médio prazo, é possível que muitas das questões regulatórias se resolvam. No entanto, a lentidão traz um risco relevante para a dinâmica do mercado em si. $\mathrm{O}$ contexto mudou e a grande disponibilidade de GNL no mercado internacional a preços muito competitivos pode criar um risco para o desenvolvimento do pré-sal.

Assim, em princípio, a crise da COVID-19 não desestruturou o processo de reforma que continua andando. Pelo contrário, os impactos macroeconômicos nos Estados e a pressão da concorrência do GNL deveriam incentivar o processo de abertura no plano

\footnotetext{
${ }^{6}$ Gasoduto Bolívia - Brasil.

${ }^{7}$ Agência Reguladora de Energia e Saneamento do Estado do Rio de Janeiro.
} 
federal e estadual. Entretanto, o ritmo lento da reforma passou a ser um risco importante para a indústria brasileira de gás.

É importante alertar, no entanto, sobre os riscos da pandemia para a indústria de gás no Brasil. A queda dos preços do gás e do petróleo no mercado internacional tem potencial para afetar de forma importante a dinâmica de crescimento da oferta doméstica. $\mathrm{O}$ aproveitamento do gás do pré-sal exige muito investimento em infraestrutura de separação do $\mathrm{CO} 2$, escoamento e tratamento. Este tipo de investimento tende a não ser prioritário no desenvolvimento dos projetos do pré-sal, principalmente se não forem rentáveis no patamar corrente de preços do gás.

No atual contexto de incertezas regulatórias e de preços de gás deprimidos, existe um risco importante do GNL capturar mercado que poderia ser suprido pelo crescimento da produção doméstica, principalmente associado aos novos produtores do pré-sal. Existe uma janela de oportunidade para a decisão da oferta do gás que é a definição do plano de desenvolvimento do campo. Não existe sentido econômico de atrasar um projeto petrolífero com gás associado para esperar um melhor momento no mercado de gás. Neste caso, a reinjeção passa a ser uma opção econômica mais viável.

Além dos preços competitivos, o GNL tem uma vantagem relevante em comparação com o gás associado que é a flexibilidade de entrega do combustível. Ademais, as soluções small-scale com entrega de GNL via caminhões - modelo de negócio em desenvolvimento - não encontram nenhum impedimento regulatório atualmente, de maneira que essa modalidade de transporte poderia se disseminar, caso seja economicamente atrativa para os consumidores.

No entanto, o suprimento a GNL não precisa concorrer com o suprimento a partir do pré-sal. As soluções podem ser complementares. Uma das dificuldades dos produtores ao negociar a venda do gás do pré-sal com as distribuidoras está na pouca flexibilidade e o relevante risco de suprimento. Um modelo de negócio vislumbrado para os novos produtores seria de criar um portfólio de suprimento, tendo o GNL como fonte de flexibilidade e adicionando segurança ao suprimento. Essa poderia ser até uma solução conjunta, unindo o interesse de mais produtores e compradores, a fim de viabilizar o grande volume de recursos de gás do pré-sal. Além disso, projetos de GNL podem contribuir para o desenvolvimento de mercado e de infraestrutura, alavancados pelos preços atuais favoráveis que posteriormente podem ser ocupados pela oferta de gás do pré-sal.

\section{Eletricidade}

A quarentena forçada e a parada abrupta da atividade econômica têm impacto significativo na demanda de energia elétrica (Gráfico 4). A redução alcançou $30 \%$ nos períodos mais severos de isolamento na Itália, país mais afetado. Além da redução do nível de consumo, a pandemia alterou o perfil horário da demanda, afetando as receitas das empresas

Econômica-Niterói, v. 22, n. 1, p. 31-57. Junho, 2020 
do setor (IEA, 2020b).

Gráfico 4 - Redução da demanda de eletricidade após medidas de lockdown

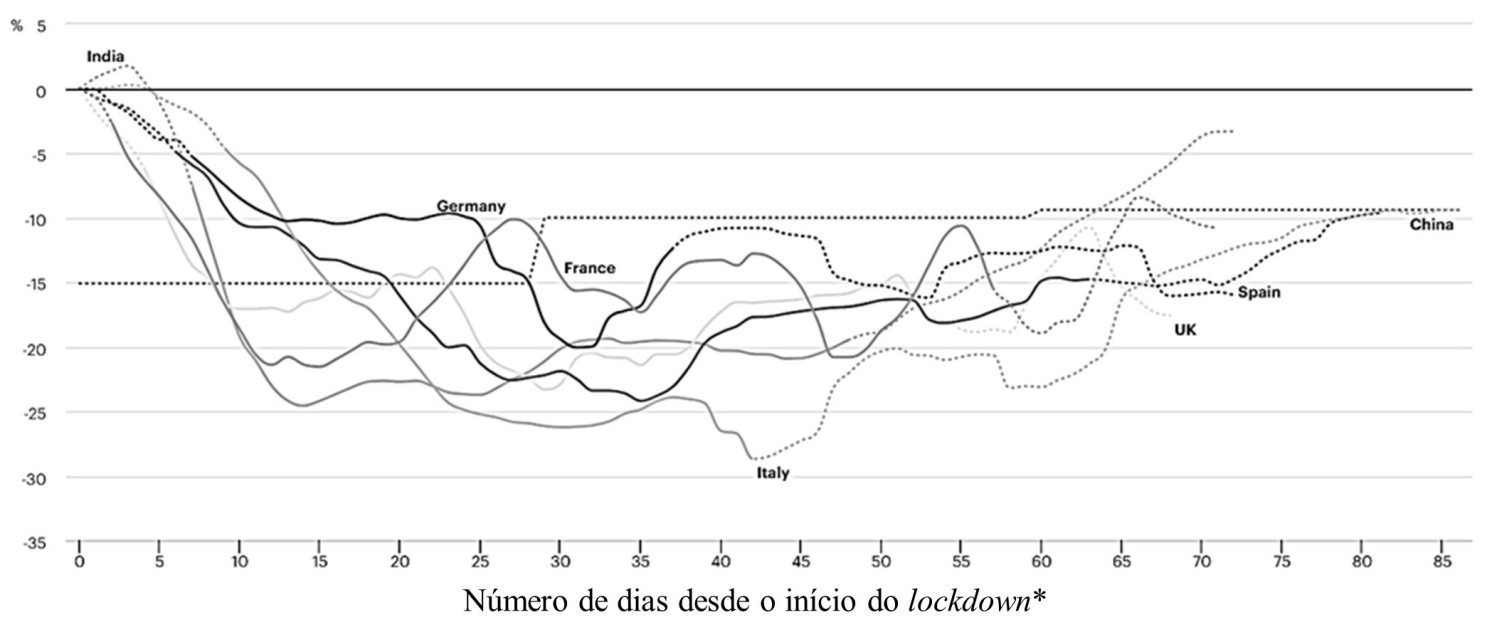

*Linhas tracejadas representam período de lockdown parcial, linhas contínuas lockdown completo

Fonte: IEA (2020c)

No Brasil, o consumo de eletricidade também foi fortemente impactado pelas medidas de isolamento para contensão do novo coronavírus. O uso de eletricidade é mais diversificado entre os segmentos de mercado, que foram impactados de forma distinta. O consumo nos segmentos industrial e comercial foi fortemente reduzido em função das medidas de isolamento social, com maior variação entre as atividades industriais. Utilizando os dados das distribuidoras, a redução de consumo foi de $28 \%$ no segmento industrial e $19 \%$ no segmento comercial e serviços, na comparação do mês de abril de 2020 frente a 2019. O consumo de eletricidade no segmento residencial aumentou $6 \%$ em abril de 2020, já que as pessoas ficaram mais em casa no isolamento.

A Tabela 2 compara a redução na carga média de eletricidade em 2020, relativamente ao mesmo período de 2019. O impacto da pandemia foi mais significativo a partir do fim de março. No auge da crise, na semana de 20/04, a queda da carga no Sistema Interligado Nacional (SIN) foi de 15,4\%. A partir de então, a redução de consumo foi menos significativa como decorrência do relaxamento das medidas de isolamento.

Por contar com perfis diferentes de consumo de eletricidade, as regiões brasileiras apresentaram dinâmicas distintas de variação da carga. A queda mais expressiva foi experimentada na região Sudeste, na semana de 20/04, de 18,56\%. Essa taxa está relacionada com a severidade das medidas de isolamento na região e com as atividades industriais desenvolvidas. Nessa mesma semana, o Nordeste experimentou sua maior queda, de $15,43 \%$. É importante destacar que algumas capitais do Nordeste passaram por medidas 
Tabela 2 - Variação da carga média semanal em relação à mesma semana do ano anterior

\begin{tabular}{cccccc}
\hline Período & SIN & $\begin{array}{c}\text { Sudeste/ } \\
\text { Centro-Oeste }\end{array}$ & Sul & Nordeste & Norte \\
\hline $16 / 03$ a $22 / 03$ & $2,18 \%$ & $2,45 \%$ & $11,16 \%$ & $-4,59 \%$ & $-4,10 \%$ \\
$23 / 03$ a $29 / 03$ & $-8,36 \%$ & $-10,14 \%$ & $-5,36 \%$ & $-8,66 \%$ & $-1,39 \%$ \\
$30 / 03$ a $05 / 04$ & $-10,92 \%$ & $-12,34 \%$ & $-9,02 \%$ & $-10,80 \%$ & $-4,95 \%$ \\
$06 / 04$ a $12 / 04$ & $-14,31 \%$ & $-16,00 \%$ & $-15,89 \%$ & $-10,72 \%$ & $-6,41 \%$ \\
$13 / 04$ a $19 / 04$ & $-10,80 \%$ & $-12,84 \%$ & $-6,32 \%$ & $-9,93 \%$ & $-7,81 \%$ \\
$20 / 04$ a $26 / 04$ & $-15,40 \%$ & $-18,56 \%$ & $-7,86 \%$ & $-15,43 \%$ & $-8,69 \%$ \\
$27 / 04$ a $03 / 05$ & $-11,35 \%$ & $-13,31 \%$ & $-3,70 \%$ & $-14,24 \%$ & $-7,42 \%$ \\
$04 / 05$ a $10 / 05$ & $-13,31 \%$ & $-15,64 \%$ & $-7,16 \%$ & $-13,85 \%$ & $-8,91 \%$ \\
$11 / 05$ a $17 / 05$ & $-9,04 \%$ & $-10,66 \%$ & $-0,48 \%$ & $-13,57 \%$ & $-5,91 \%$ \\
$18 / 05$ a $24 / 05$ & $-8,05 \%$ & $-8,38 \%$ & $-2,39 \%$ & $-14,33 \%$ & $-4,42 \%$ \\
$25 / 05$ a $31 / 05$ & $-12,25 \%$ & $-16,37 \%$ & $-4,14 \%$ & $-10,73 \%$ & $-4,11 \%$ \\
\hline
\end{tabular}

Fonte: Elaboração própria a partir de ONS (2020)

de isolamento mais rigorosas em meados de maio (como o lockdown em São Luís, Fortaleza e Recife) o que colaborou para acentuar a queda na carga. O Norte, que apresenta elevada participação do segmento industrial (43\%), tem consumo concentrado no segmento metalúrgico, que foi menos impactado que outros ramos de atividade. O Sul, que até maio sofreu em menor magnitude as consequências da pandemia, não experimentou quedas tão significativas na carga.

Os dados da Câmera de Comercialização de Energia Elétrica (CCEE, 2020a) - Tabela 3 - indicam que a redução de consumo de eletricidade foi mais representativa em clientes de grande porte. Ao se fazer uma comparação entre os meses de maio de 2019 e 2020, houve uma redução de 12,9\% no consumo de energia para o Ambiente de Contratação Livre (ACL). O setor automotivo foi o mais afetado, cujo consumo caiu quase $48 \%$. Queda parecida também foi experimentada pelo segmento têxtil, de mais de $46 \%$. Por outro lado, os setores alimentícios e de saneamento foram os únicos a experimentaram um consumo maior de energia, com destaque para o segundo, cuja variação ultrapassou os $22 \%$.

A queda no consumo durante a pandemia é semelhante àquela ocorrida durante o período de racionamento, entre 2001 e 2002, uma referência de crise setorial. No entanto, é importante ressaltar que as motivações para brusca redução do consumo de eletricidade no período de pandemia e na época do racionamento são distintas. Enquanto a pandemia causou um choque negativo na demanda, o racionamento foi decorrência de uma crise de oferta, fazendo com que a população tivesse que mudar radicalmente seus hábitos de consumo para evitar um apagão.

Considerando a média de carga nas 15 semanas anteriores ao racionamento, de 13/02 a 27/04/2001, e a média das quinze semanas em que o consumo foi mais impactado, de

Econômica-Niterói, v. 22, n. 1, p. 31-57. Junho, 2020 
Tabela 3 - Consumo de energia por atividade para o mês de maio, em MW médio

\begin{tabular}{lccc}
\hline Atividade & 2019 & 2020 & Variação \\
\hline Veículos & 838 & 436 & $-47,97 \%$ \\
Têxteis & 622 & 335 & $-46,14 \%$ \\
Serviços & 1.198 & 840 & $-29,88 \%$ \\
Transporte & 253 & 188 & $-25,69 \%$ \\
Manufaturados Diversos & 1.569 & 1.284 & $-18,16 \%$ \\
Químicos & 1.982 & 1.697 & $-14,38 \%$ \\
Minerais Não-metálicos & 1.876 & 1.758 & $-6,29 \%$ \\
Madeira, Papel e Celulose & 1.193 & 1.128 & $-5,45 \%$ \\
Bebidas & 244 & 233 & $-4,51 \%$ \\
Metalurgia e Produtos do Metal & 4.720 & 4.540 & $-3,81 \%$ \\
Telecomunicações & 210 & 203 & $-3,33 \%$ \\
Extração de Minerais Metálicos & 1.310 & 1.283 & $-2,06 \%$ \\
Comércio & 877 & 868 & $-1,03 \%$ \\
Alimentícios & 1.799 & 1.845 & $2,56 \%$ \\
Saneamento & 258 & 316 & $22,48 \%$ \\
\hline
\end{tabular}

Fonte: Elaboração própria a partir de CCEE (2020a)

09/06 a 21/09/2001, a redução de carga no SIN foi de 23\%. A redução foi mais significativa nos subsistemas Sudeste/Centro-Oeste e Nordeste, de 26\%. Mesmo as regiões que inicialmente não foram incluídas no racionamento, Norte e Sul, tiveram redução de carga superior a $10 \%$ (ONS, 2020). No caso do racionamento, a queda do consumo ocorreu de forma mais gradual e duradoura. O consumo de eletricidade só retornou aos níveis prévios ao racionamento após um ano e meio.

A redução de consumo desestrutura as finanças do setor elétrico. As receitas da cadeia produtiva se reduzem, em grande parte, de forma proporcional ao consumo. Considerando uma tarifa média de eletricidade no Brasil de R\$ 510,44, Losekann e Rodrigues (2020) estimaram a perda de receita mensal no Ambiente de Contratação Regulado (ACR) de $\mathrm{R} \$ 1,8$ bilhões. As perdas de receita nos dois ambientes de contratação de eletricidade totalizariam $\mathrm{R} \$ 2,6$ bilhões mensais ${ }^{8}$. O Boletim do Ministério de Minas e Energia (MME, 2020a) indica que, em 07/06, as distribuidoras de eletricidade perderam receitas de $\mathrm{R} \$ 3,1$ bilhões desde o início do isolamento, em relação ao mesmo período em 2019.

$\mathrm{Na}$ época do racionamento, para lidar com os impactos financeiros, foi negociado o Acordo Geral do Setor Elétrico (Lei 10.438/02) entre consumidores, geradoras e distribuidoras que instituiu: (i) descontratação de energia para compensar a redução de consumo; (ii) revisão tarifária extraordinária (RTE) das distribuidoras; e (iii) concessão de emprés-

\footnotetext{
${ }^{8}$ Esta é uma estimativa simplificada, que não leva em conta as parcelas fixas das tarifas de eletricidade, considerando, de forma simplificada, um valor médio de aquisição de energia de R\$ 250/MWh.
} 
timos emergenciais do BNDES de até $90 \%$ das perdas resultantes do racionamento (Esposito, 2012).

As distribuidoras que ficaram com descasamento entre receita e custos receberam financiamentos para compensar a perda de receita até o momento da revisão ( $\mathrm{R} \$ 5,4$ bilhões em valores correntes) e para compensar os custos adicionais de aquisição de energia (Parcela $\mathrm{A}$ ) enquanto não era possível repassá-los através dos reajustes anuais (R $\$ 1,7$ bilhões). As geradoras receberam financiamento de $\mathrm{R} \$ 2,2$ bilhões para compensar sua exposição ao mercado de curto prazo (MAE). Os aportes do BNDES totalizaram R \$ 9,3 bilhões em valores correntes, ou $\mathrm{R} \$ 20,7$ bilhões em preços atuais ${ }^{9}$.

Algumas considerações sobre as diferenças entre as situações pós-racionamento e a atual devem ser feitas para avaliar a replicação dessas medidas. A primeira consideração é que as medidas pós-racionamento foram focadas nas distribuidoras. O mercado livre ainda era nascente e representava $1 \%$ do consumo total de eletricidade. Hoje o mercado livre é bem mais representativo e alcança $30 \%$ do consumo total de eletricidade (CCEE, 2020a). A quantidade de agentes se multiplicou. Havia 95 agentes atuando no mercado livre em 2001 e, hoje, há 9 mil (CCEE, 2020b).

Outra consideração é que o impacto da COVID-19 sobre as finanças setoriais tende a ser muito mais modesto do que o ocorrido no racionamento. $\mathrm{O}$ consumo no racionamento de 2001 teve redução mais significativa, já que se estendeu sobre todos os segmentos de mercado e de forma mais duradora. A receita com fornecimento de eletricidade das distribuidoras foi $\mathrm{R} \$ 162$ bilhões em 2019 (ANEEL, 2020). Cada mês de isolamento implicaria em reajuste de $1,1 \%$ na tarifa das distribuidoras em termos anuais para reequilibrar suas receitas. Ao contrário do racionamento de 2001, dessa vez não há impacto da exposição ao mercado de curto prazo, pois os preços estão mais próximos ao piso.

Outro aspecto que agrava as finanças do setor é a inadimplência, cuja evolução futura é difícil de estimar. Segundo MME (2020a), a inadimplência média desde o início do isolamento é de $8,1 \%$. A inadimplência vem caindo e, nos últimos 30 dias que se encerraram em 07/06, foi menor que em igual período de 2019. A perda de receita de distribuidoras em função do aumento da inadimplência somou $\mathrm{R}$ \$ 3,3 bilhões desde o início do isolamento até a primeira semana de junho.

Em tempos excepcionais, experiências de países europeus apontam para medidas paliativas sobre o faturamento e a continuidade de fornecimento das utilities: tratamento especial a vulneráveis; suspensão de corte por inadimplemento; e diferimento com parcelamento de débitos. Enquanto se garante o fornecimento de serviços essenciais e se mitiga a inadimplência com transferências de renda à população, o funcionamento dos mercados liberalizados de energia acomoda a queda do consumo, transmitindo o ajuste por toda a cadeia (Romeiro, 2020).

No Brasil, a ANEEL vetou, por 90 dias, a interrupção por inadimplemento de consu-

\footnotetext{
${ }^{9}$ Valores atualizados pelo IPCA.
} 
midores residenciais; estendeu prazos processuais; flexibilizou intervalos de leitura, permitindo autoleitura ou estimativa pela média; postergou reajustes tarifários; e autorizou o repasse antecipado de fundos para alívio futuro de encargos (R 2 bilhões).

Adicionalmente, a Medida Provisória $\mathrm{n}^{\circ}$ 950/2020 isentou, por 3 meses, o pagamento das contas dos beneficiários da tarifa social (9 milhões, cerca de 13\% das unidades consumidoras) pelo consumo de até $220 \mathrm{kWh} / \mathrm{mês}$, através do aporte de R 900 milhões do Tesouro na Conta de Desenvolvimento Energético. A MP 950 também autorizou a realização de empréstimos para compensar a perda de receita das distribuidoras, com repasse de encargos tarifários futuros ${ }^{10}$.

Regulamentando a MP 950, o Decreto $n^{\circ}$ 10.350/2020 estruturou a criação e a gestão da Conta- COVID, para cobrir déficits ou antecipar receitas de distribuidoras em decorrência da COVID-19, incluindo, entre outras rubricas, os custos da sobre contratação de energia em 2020. Através de empréstimos bancários sindicalizados, o fluxo de receitas do setor será preservado, garantindo a receita das transmissoras e geradoras, com repasse tarifário futuro em até 60 parcelas aos consumidores. A Resolução Normativa da ANEEL $n^{\circ} 885 / 2020$ estabeleceu o limite da operação de crédito para cada concessionária, com valor total limitado a R \$ 16 bilhões ${ }^{11}$. Já o eventual reequilíbrio econômico-financeiro das distribuidoras ainda é objeto de discussão em curso na ANEEL.

O empréstimo para as distribuidoras é fonte segura para recursos bancários em momento de excesso de liquidez e elevada aversão ao risco do sistema financeiro. Ao preservar o caixa das distribuidoras para cobrir as obrigações contratadas com geradores e transmissores, a despeito da queda de demanda observada, os empréstimos asseguram a solvência e adimplência desses agentes em seus financiamentos, mitigando perdas da própria exposição bancária ao setor. Em contexto de elevada incerteza, perdas generalizadas na economia e incapacidade de articulação entre esferas administrativas do governo, a rápida resposta do setor elétrico à crise preservou as receitas da cadeia às custas do mercado regulado (consumidores cativos). Assim, o setor elétrico destoa pela rápida composição para garantir recursos; porém, os instrumentos apoiam-se excessivamente na centralização do setor e no mercado regulado. A Conta-COVID confere fôlego momentâneo ao setor, mas compromete ainda mais a capacidade de pagamento após a crise. A resposta é antes um alerta do que uma solução, em um setor que ensaia há cinco anos reformas inconclusas em direção a maior liberalização da comercialização de energia. A reestru-

\footnotetext{
${ }^{10}$ A MP 950 caducou no Congresso após impasse com inúmeras emendas ao texto submetido. Isto não impediu, entretanto, a assinatura dos contratos da Conta-COVID e a aplicação dos descontos tarifários na sua vigência, sem necessitar de conversão em lei.

${ }^{11}$ Quase a totalidade das concessionárias de distribuição aderiu ao empréstimo sindicalizado, somando R \$ 14,8 bilhões. Os bancos públicos serão responsáveis por cerca de $30 \%$ da oferta. Coordenado pelo BNDES, o empréstimo será financiado a taxa CDI + 3,79\% a.a., com carência até julho de 2021 e vencimento em dezembro de 2025. O BNDES, que coordena o consórcio bancário, também viabilizou o standstill dos financiamentos de longo prazo, oferecendo a todos setores da economia em sua carteira a suspensão temporária de pagamentos de principal e juros, com capitalização no saldo devedor e sem alteração do prazo final.
} 
turação efetiva reclama por outros caminhos mais funcionais e eficientes, com menores encargos e maior competitividade.

\section{Considerações Finais}

A COVID-19 se revelou bastante desafiadora para os mercados energéticos, trazendo inúmeros desafios global e nacionalmente. Embora ainda seja cedo para visualizar o tamanho do nó econômico no setor energético, é possível vislumbrar quais ameaças pairam sobre o setor e quais deveriam ser as prioridades de uma ação de resposta do governo. Dentre eles, destacam-se a segurança no abastecimento, no curto prazo, e a sustentabilidade da indústria, nos médio e longo prazos. Conferir uma atenção especial ao setor energético se mostra indispensável devido a sua essencialidade.

Para o setor de petróleo, caso se confirme o cenário lower for longer, será necessária uma forte adaptação por parte das empresas. A primeira barreira a ser superada é a própria viabilidade econômica de alguns projetos. A segunda se refere à trajetória de transição energética, em que fontes energéticas fósseis são substituídas por renováveis. Nesse contexto, uma possível maneira de contornar essas barreiras seria a adoção de estratégias agressivas de inovação. As cláusulas de $\mathrm{P} \& \mathrm{D}$ permitiram o desenvolvimento de um grande ecossistema de inovação, envolvendo fornecedores, universidades e start-ups tecnológicas.

No caso dos combustíveis derivados, a lenta recuperação dos preços do petróleo pode prejudicar as decisões de investimentos. Nesse sentido, é importante repensar tanto as estratégias empresariais quanto a política energética para o setor. Para os biocombustíveis, a situação se mostra ainda mais crítica, já que o etanol se mostrará ainda menos competitivo frente à gasolina. Assim, o açúcar deverá ser cada vez mais o produto prioritário das usinas. Apesar da demanda por açúcar ser uma das mais inelásticas dentre as commodities, este mercado não está imune à crise.

Para o mercado de gás, a pandemia coincidiu e impactou nas medidas de liberalização do setor e redução da dominância da Petrobras. As ações de curto prazo de enfrentamento da crise foram caracterizadas pela administração da oferta doméstica e importada pela Petrobras. O médio e longo prazo, a maior abundância de gás no mercado internacional, em particular do GNL, representa um grande desafio para a viabilidade dos investimentos para aproveitamento do gás do pré-sal. Nesse sentido, é fundamental uma política de estímulos ao aproveitamento do gás associado no Brasil e foco na resolução das questões em aberto no processo de liberalização do segmento.

Em se tratando do setor elétrico, a ação do Estado nesse primeiro momento deve ir na direção da preservação dos fluxos de pagamento, principalmente no mercado cativo. A aprovação da Conta-COVID vai de encontro à essa ação. No mercado livre, os agentes estão inerentemente expostos a maiores riscos, o que é precificado através de livre negoci-

Econômica-Niterói, v. 22, n. 1, p. 31-57. Junho, 2020 
ação. Nesse caso, a ação do Estado deve ser orientada a evitar a judicialização excessiva, que pode paralisar sua funcionalidade. Em relação aos pequenos consumidores, apesar de o Brasil ter aprovado medidas de alívio, não foram definidos planos de diferimento e parcelamento das faturas. Se por um lado, confere isenção à parcela mais vulnerável da população; por outro, sinaliza a cobertura de custos para além da inadimplência, compensando a sobrecontratação de energia do mercado regulado com aumento tarifário futuro, o que comprometerá ainda mais a capacidade de pagamento após a crise.

Após superados os impactos da pandemia nos mercados energéticos no curto prazo, haverá uma tendência mundial, de longo prazo, em dar mais importância à questão ambiental. Analisando os mercados de energia como um todo, a crise sanitária deve acelerar a transição energética, já que muitos dos estímulos à recuperação das economias estarão condicionados à uma descarbonização. Almeida (2020) aponta que haverá uma tendência de maior apoio às fontes renováveis de energia, enquanto fontes fósseis devem ser penalizadas, seja via taxação ou via mercados de carbono. Maiores suporte e estímulo às renováveis, aliados a uma penalização das fósseis, devem resultar em ganhos ainda mais significativos, principalmente em termos de custos, para as fontes renováveis de energia. Espera-se, portanto, uma profunda mudança estrutural nos mercados energéticos mundiais.

No caso do Brasil, apesar de a matriz energética nacional contar com expressiva participação de energias renováveis, as perspectivas de longo prazo são positivas. Para a expansão de geração eletricidade, as fontes eólica e solar fotovoltaica devem continuar ganhando espaço. No caso dos biocombustíveis, a tendência é um reforço à sua importância, principalmente no âmbito do RenovaBio. Em relação ao petróleo, Almeida (2020) aponta vantagens para a indústria nacional, já que as emissões de gases poluentes provenientes da exploração de petróleo no pré-sal correspondem à metade das emissões médias mundiais. Por fim, o crescimento do gás natural no Brasil consiste em uma grande oportunidade para substituição de fontes mais poluentes, como o carvão. Portanto, a tendência é que o Brasil siga, também, por trajetórias energéticas mais sustentáveis. 


\title{
Impacts of COVID-19 in the Brazilian Energy Markets
}

\begin{abstract}
Energy markets have been severely affected by the new coronavirus pandemic. The measures adopted to face COVID-19, mainly the mobility restrictions, resulted in significant reductions in the global energy demand. Brazilian flaws in combating the pandemic had an impact on the dynamics of energy markets. The energy consumption fall in Brazil was less significant than countries that have already experienced the pandemic peak, but it tends to be more persistent. This article aims at providing an overview of the impacts of the pandemic on the oil, fuel and biofuels, gas and electricity markets in Brazil. Also, we discuss the challenges and draw some prospects for Brazilian energy markets in the post-pandemic.
\end{abstract}

Keywords: Petroleum, Fuels, Biofuels, Gas, Electricity

JEL: D40, L51, Q40

\section{Referências bibliográficas}

ABEAR (2020). Demanda por voos domésticos cai 90,97\% em maior. Disponível em $<$ https://www.abear.com.br/imprensa/agencia-abear/noticias/demanda-por-voos-domesticoscai-9097-em-maio/>. Acesso em 28 de julho de 2020.

ALMEIDA, E. L. F. (2020). A Retomada do Setor de Energia: Aceleração de Tendências e Mudanças Estruturais. Ensaio Energético, 28 de setembro, 2020.

ANEEL (2020). Agência Nacional de Energia Elétrica. Ranking dos agentes por receita. Disponível em <https://www.aneel.gov.br/relatorios-de-consumo-e-receita > Acesso em 10 de junho de 2020.

ANP (2019). ANP divulga agenda regulatória no âmbito do Novo Mercado de Gás. Notícia divulgada no site da ANP, de 24 de julho de 2019. Disponível em $<$ http://www.anp.gov.br/noticias/5278-anp-divulga-agenda-regulatoria-no-ambito-do-novomercado-de-gas $>$. Acesso em 10 de junho de 2020.

ANP (2020a). Agência Nacional do Petróleo. Produção de Petróleo e Gás no Brasil ultrapassa 4 milhões de boe/d pela primeira vez. Disponível em <http://www.anp.gov.br /noticias/5628-producao-de-petroleo-e-gas-no-brasil-ultrapassa-4-milhoes-de-boe-d-pelaprimeira-vez>. Acesso em 10 de junho de 2020.

ANP (2020b). Agência Nacional do Petróleo. Painéis Dinâmicos do Abastecimento.

Econômica-Niterói, v. 22, n. 1, p. 31-57. Junho, 2020 
Disponível em <http://www.anp.gov.br/distribuicao-e-revenda/paineisdinamicos-abastecimento $>$. Acesso em 10 de junho de 2020.

ANP (2020c). Agência Nacional do Petróleo. Importações e Exportações. Disponível em: <http://www.anp.gov.br/dados-abertos-anp/importacoes-exportacoes>. Acesso em 10 de junho de 2020.

ANP (2020d). Agência Nacional do Petróleo. Notícias. Disponível em $<$ http://www.anp.gov.br/noticias/5717-17-rodada-e-suspensa $>$. Acesso em 10 de junho de 2020.

ANP (2020e). Agência Nacional do Petróleo. Série história do levantamento de preços e de margens de comercialização de combustíveis. Disponível em $<$ http://www.anp.gov.br/precos-e-defesa-da-concorrencia/precos/levantamento-de-precos /serie-historica-do-levantamento-de-precos-e-de-margens-de-comercializacao-decombustiveis>. Acesso em 10 de junho de 2020.

ANP (2020f). Agência Nacional do Petróleo. Preços de produtores e importadores de derivados de petróleo. Disponível em <http://www.anp.gov.br/precos-e-defesa-daconcorrencia/precos/precos-de-produtores $>$. Acesso em 10 de junho de 2020.

ANP (2020g). Informações de mercado. Disponível em http://www.anp.gov.br/ producao-de-biocombustiveis/etanol/informacoes-mercado-etanol. Acesso em 28 de junho de 2020.

ANP (2020h). Agência Nacional do Petróleo. Notícias. Disponível em: http://www.anp.gov.br/noticias/5795-anp-reduz-temporariamente-percentual-de-biodieselmisturado-ao-diesel. Acesso em 10 de junho de 2020.

ANP (2020i). Boletim da Produção de Petróleo e Gás Natural. Edição Abril 2020/ Número 116. Disponível em <http://www.anp.gov.br/arquivos/publicacoes/boletins-anp/ producao/2020-04-boletim.pdf>. Acesso em 10 de junho de 2020.

BACON, R. W. (1991). Rockets and feathers: the asymmetric speed of adjustment of UK retail gasoline prices to cost changes. Energy Economics, 13, issue 3, pp. 211-218.

BCB (2020). Banco Central do Brasil. Cotações e Boletins.

BNDES (2020). Banco Nacional de Desenvolvimento Econômico e Social. Programa BNDES de Apoio ao Setor Sucroalcooleiro. Disponível em $<$ https://www.bndes.gov.br/ wps/portal/site/home/financiamento/produto/programa-bndes-de-apoio-ao-setorsucroalcooleiro>. Acesso em 10 de junho de 2020.

CCEE (2020a). Câmara de Comercialização de Energia Elétrica. Infomercado Quinzenal $2302^{a}$ Edição, maio de 2020. Disponível em <http://www.ccee.org.br/portal/faces/ pages_publico/o-que-fazemos/infomercado/info_mercado_interativo?>. Acesso em $20 \mathrm{de}$ junho de 2020.

CCEE (2020b). Câmara de Comercialização de Energia Elétrica. Infomercado Dados Gerais 2020. Disponível em <https://www.ccee.org.br/portal/faces/pages_publico/o-que- 
fazemos/infomercado>. Acesso em 15 de junho de 2020.

CEPEA (2020). Indicador semanal do etanol hidratado combustível Cepea/Esalq - São Paulo. Disponível em <https://www.cepea.esalq.usp.br/br/indicador/etanol.aspx>. Acesso em 17 de junho de 2020.

CNPE (2019). Conselho Nacional de Política Energética. Resolução no 16/2019. Disponível em <http://www.mme.gov.br/documents/36112/491934/1.+Resolu\%C3\%A7\% C3\%A3o_CNPE_16_2019.pdf/2d2e22aa-b6d8-d939-4eab-826b117f560b>. Acesso em 10 de junho de 2020.

CONAB (2020). Companhia Nacional de Abastecimento. Boletim da safra de canade-açúcar. Disponível em <www.conab.gov.br/info-agro/safras/cana/boletim-da-safra-decana-de-acucar>.

Acesso em 10 de junho de 2020.

EIA (2020a). United States Energy Information Administration. Petroleum and Other Liquids. Disponível em <https://www.eia.gov/dnav/pet/PET_PRI_SPT_S1_D.htm>. Acesso em 10 de junho de 2020.

EIA (2020b). United States Energy Information Administration. Short-term Energy Outlook. Disponível em < https://www.eia.gov/outlooks/steo/>. Acesso em 10 de junho de 2020.

ESPOSITO, A. S. (2012). O setor elétrico brasileiro e o BNDES: reflexões sobre o financiamento aos investimentos e perspectivas. Disponível em <https://web.bndes.gov.br/ bib/jspui/handle/1408/920>. Acesso em 10 de junho de 2020.

IEA (2020a). International Energy Agency. Global Energy Review - The Impacts of the Covid 19 crises on global energy demand and CO2 emissions. Disponível em $<$ https://www.iea.org/reports/global-energy-review-2020>. Acesso em 10 de junho de 2020.

IEA (2020b). Gas 2020. Disponível em <https://webstore.iea.org/gas-2020>. Acesso em 17 de junho de 2020.

IEA (2020c). Covid-19 impact on electricity, Report. Disponível em $<$ https://www.iea.org/ reports/covid-19-impact-on-electricity>. Acesso em 14 de setembro de 2020.

LOSEKANN, L.; RODRIGUES, N. (2020). Energia Hoje. Impactos da Covid-19 na demanda de eletricidade e implicações no Brasil. Disponível em:

$<$ https://energiahoje.editorabrasilenergia.com.br/impactos-da-covid-19-na-demanda-deeletricidade-e-implicacoes-no-brasil/>. Acesso em 12 de junho de 2020.

MDCI (2020). Séries Históricas. Disponível em <http://www.mdic.gov.br/comercioexterior/estatisticas-de-comercio-exterior/series-historicas $>$. Acesso em 28 de julho de 2020.

MILANEZ, A. Y.; NYKO, D.; GARCIA, J. L. F.; REIS, B. L. S. F. S. (2012). O

Econômica-Niterói, v. 22, n. 1, p. 31-57. Junho, 2020 
déficit da produção de etanol no Brasil entre 2012 e 2015: determinantes, consequências e sugestão de política. BNDES Setorial 35, Biocombustíveis, pp. 277-302.

MME (2020a). Ministério de Minas e Energia. Boletim de Monitoramento Covid-19. Brasília. Disponível em <http://www.mme.gov.br/web/guest/covid-19>. Acesso em 26 de julho de 2020.

MME (2020b). Boletim Mensal de Acompanhamento da Indústria de Gás Natural. Disponível em <http://www.mme.gov.br/web/guest/secretarias/petroleo-gas-naturale-combustiveis-renovaveis/publicacoes/boletim-mensal-de-acompanhamento-da-industriade-gas-natural>. Acesso em 26 de julho de 2020.

NYKO, D.; VALENTE, M. S.; MILANEZ, A. Y.; TANAKA. A. K. R.; RODRIGUES, A. V. O. (2013). A evolução das tecnologias do setor sucroenergético: estagnação passageira ou crise estrutural? BNDES Setorial 37, Bioenergia, pp. 399-442.

ONS (2020). Operador Nacional do Sistema Elétrico. Histórico da Operação - Carga de Energia. Disponível em <http://www.ons.org.br/Paginas/resultados-da-operacao/ historico-da-operacao/carga_energia.aspx>. Acesso em 17 de julho de 2020.

PETROBRAS (2016). Petróleo Brasileiro S.A. Fatos e Dados. Disponível em $<$ http://www.petrobras.com.br/fatos-e-dados/adotamos-nova-politica-de-precos-de-diesele-gasolina.htm>. Acesso em 17 de julho de 2020.

PETROBRAS (2020a). Petróleo Brasileiro S.A. Relações com Investidores. Comunicados ao Mercado: Petrobras bate recorde de exportação de petróleo em abril.

PETROBRAS (2020b). Petróleo Brasileiro S.A. Relações com Investidores. Central de Resultados.

PETROBRAS (2020c). Petróleo Brasileiro S.A. Relações com Investidores. Comunicados ao Mercado: Petrobras sobre produção de petróleo em abril (07/04/2020).

PETROBRAS (2020d). Petrobras sobre ações na cadeia de gás natural. Comunicado ao mercado - 09 de abril de 2020. Disponível em <https://api.mziq.com/mzfilemanager/ v2/d/25fdf098-34f5-4608-b7fa-17d60b2de47d/94acfecf-4b67-69e0-3c3e-6e918813f3ef? origin=1>. Acesso em 17 de julho de 2020.

ROMEIRO, D. L. (2020). Prestação e Faturamento de Serviços Essenciais em Tempos Excepcionais do Covid-19. Brasil Energia. Disponível em:

$<$ https://editorabrasilenergia.com.br/prestacao-e-faturamento-de-servicos-essenciais-emtempos-excepcionais-do-covid-19/>. Acesso em 07 de junho de 2020.

Recebido em 30 de junho de 2020. Aceito para publicação em 29 de novembro de 2020. 